\title{
Effect of Personality on Speaking Skills of Language Departement in SMA Negeri 1 Sawan
}

\section{Kadek Dwi Cahyani1 ${ }^{*}$, I Made Sutama ${ }^{2}$, I Wayan Rasna ${ }^{3}$}

123 Language Education, Post Graduate Study Program, Ganesha University Of Education

\section{A R T I C L E I N F O Article history: \\ Received February 2020 \\ Received in revised \\ Form 01 March 2020 \\ Accepted 18 April 2020 \\ Available online 30 May 2020}

\section{Keywords:}

Effect , Personality, and Speaking Skills

\begin{abstract}
A B S T R A C T
This study aimed to know the effect of personality on speaking skills of Language Departement in SMA Negeri 1 Sawan. The population in this study were 106 students from 3 classes. Purposive Sampling was used as the sampling technique in this study. The number of samples in this study were 70 students, consisting of 30 introvert students and 40 students with extrovert personalities. The research method was Ex Post Facto research design. The data were analyzed by using T-test and the significance level was $\alpha=0.005$. The data were collected by using questionnaire and test. The results showed that there was an effect of personality on students' speaking skills, with the significance value 0,000 less than 0.005 and it was seen from the average score of extrovert students' speaking skills was 83.47 meanwhile the average score of introvert students' speaking skills was 79.60. So, H0 is rejected and H1 is accepted.
\end{abstract}

\section{Introduction}

Language skills are something important for everyone to master. In a society, everyone interacts with other people by communicating. It cannot be denied that language skills are one of the important elements that determine their success in communication. Can be imagined if we do not have language skills. We cannot express thoughts, cannot express feelings, and cannot report the facts that we observe. On the other hand, we cannot understand the thoughts, feelings, ideas, and facts that people convey to us. One language skill, namely speaking skills. Speaking skills have an important role in efforts to give birth to future generations that are intelligent, creative, critical and cultured. By mastering speaking skills, students are able to express their thoughts and feelings intelligently according to the material and situation when speaking. Speaking skills are also able to form creative future generations so that they are able to speak communicatively, clearly, coherently, easily understood. In addition, speaking skills are also capable of giving birth to critical future generations because they have the ability to express ideas, thoughts, or feelings to others in a systematic and gradual manner. According to Vygotsky (in Aisyah, 2007) speaking is central which is important in the learning process. He believes that the development of speech is directly related to cognitive development.

One thing we need to know together is that every human being has a way of absorbing and processing the information he receives in ways that are different from each other. This depends on the personality of each individual. According to Supriadi in (Syamsu Yusuf, 2005) personality is the quality of individual behavior that appears in adjusting itself to a unique environment. students who do not have strong personality tend to be weak, easy to change, not opinionated, hesitant in acting and irresponsible which will have a negative impact on the development of the student itself, therefore a teacher must first recognize the types the student's personality for the smooth learning process.

Carl Gustav Jung (in Nana Syaodih Sukmadinata, 2004: 145) distinguishes two personality types namely extrovert and introvert. Someone who has an Extrovert type tends to prioritize the interests of his environment rather than his own interests, this type also has an open person and who has an introverted type who tends to be more reclusive from his environment.

Personality really needs to be known and learned because personality is closely related to the pattern of acceptance of the social environment towards someone. In addition, personality needs to be 
known so that we can know our own learning methods. Especially in the acquisition of language, someone who has an extroverted personality tends to like to speak in language processing, even speaking highly demanded, while those who have objective views. An introvert is more focused on the values that are in accordance with him, and many of his actions are based on his own ideals and thoughts. Students with personality types with introverted students tend to be quiet and like reading in the acquisition of language is very necessary. In addition, people who have a personality in accordance with the pattern adopted by the community in their environment, will experience good acceptance, but on the contrary if a person's personality is not appropriate, especially contrary to the pattern adopted by his environment, there will be rejection from the community. between the personality possessed by the social environment, then there will be a balance between the two, on the contrary if there is a discrepancy between the two, then there will be consequences, namely the person will seek the appropriate social environment or will make adjustments to his social environment.

In the process of learning Indonesian in the X language class of SMA 1 Sawan, especially in speaking skills, it appears that student scores are different. Talking students have higher intensity scores than students who are silent and talk as needed in the classroom and also student learning behavior in the class is different. Yag where one student always responds positively to the things expressed by the teacher and wants to answer the questions given by the teacher, on the other hand there are students who are just silent not answering and shy if the teacher asks.

That is what encourages researchers to conduct research in the field with the focus being studied, namely the personality of students who are extroverted and introverted towards speaking and writing skills. Therefore, an interesting problem arises to be examined, namely whether there is an influence of student personality on the speaking skills of class X students of SMA Negeri 1 Sawan.

\section{Methods}

This research is classified as quantitative research, namely the type of research that is characteristic in the form of numbers whose data is analyzed based on statistical formulas (Sugiyono, 2017: 7). This type of research is a type of non-experimental imperative study. With the design of the study is ex post facto which is an assessment carried out to examine the events that have occurred and then trace back to find out the factors that can lead to these activities (Sugiyono, 2008: 7). Based on the level of exploration, this study is classified as research descriptive verification. Descriptive verification research is research conducted to determine the value of independent variables, either one variable or more (independent) without making comparisons or connecting with other variables (Sugiono, 2008: 11). In this study, the personality of students will be measured by two personality types in which the personality referred to in this study is an Extrovert and Introvert personality type. Extroverted personality is a personality type that is super active, likes to socialize and likes to talk. While the Introverted personality type is a personality type that is generally aloof, does not like to socialize and likes to read. Both of these personality types will be obtained from the results of giving questionnaires to students, revealed through the number of values obtained from the scale items EPQ (Eyesenck Personality Questionnaire) this scale is a modification of the Extrovert-Introvert scale compiled by Eyesenck in Wilson (1982) which translated by Dwipayana (2016) and validated. The value obtained is in accordance with the specified scale.

After being known to students who have Extrovert and introverted personalities, the speaking skills orientation is obtained from the results of debate practice skills in accordance with class X material. The teacher gives a motion then students who have an Extrovert or introvert personality practice it according to the skills possessed by the student. The teacher gives a score for students who speak when the debate begins. Scores are given based on aspects of speaking skills. The students' speaking skills measured the debate score obtained, the higher the value obtained, the higher the speaking aspect of Extrovert and introverted students, however, if the scores obtained were low, the speaking aspects of Extrovert and introverted students were also low.

The population in this study were all students of class X language Sawan 1 High School in the even semester in the 2018/2019 school year. Which consists of 3 classes, namely class X Language I, X Language II, X Language III which is as many as 106 students. Determination of the sample of this study was done by purposive sampling technique that is the technique of determining the subject according to certain characteristics that have been determined by the researcher. The characteristics intended here are students who are extroverted and introverted. The sample to be used in this study amounted to 70 people from 40 students with an extroverted personality type and 30 students with an introverted personality type based on observations and also the results of questionnaires that had been distributed to the $\mathrm{X}$ Language Class of Sawan 1 Public High School. 
The methods and instruments of data collection used were questionnaires and tests. The questionnaire method is also called the questionnaire method or in English it is called a questionnaire. The questionnaire method is a series or list of questions that are arranged systematically, then sent for puladiisi by respondents. After filling out, the questionnaire is sent back or returned to the officer or researcher. (Buhan Bungin, 2009: 123)

In this study, the questionnaire method was distributed to respondents in this case were students of class X SMA N 1 Sawan to be answered to obtain data on personality outcomes of students who were introverted and Extroverted. Measurement of personality type measured from the value of the questionnaire that has been given using the scale EPQ (Eyesenck Personality Questionnaire) This scale is a modification of the Extrovert-introvert scale compiled by Eyesenck in Wilson (1982) which is translated by Dwipayana (2016) and has been validated.

In the questionnaire, the number of personality values in the questionnaire contained five answers with positive and negative questions. On positive questions: very appropriate (SS) given a scale of 5 , according to (S) given a scale of 4 , inappropriate (KS) given a scale of 3 , inappropriate (TS) given a scale of 2, and very inappropriate (STS) given a scale of 1 . While the negative questions are very suitable (SS) given a scale of 1 , according to (S) given a scale of 2, inappropriate (KS) given a scale of 3 , inappropriate (TS) given a scale of 4, and very inappropriate (STS) given a scale of 5 .

Data analysis was carried out in this study to determine whether or not there was an influence between students' personality on speaking skills. Score data of students' speaking skills will be tested by ttest.

The time in this study is on the effective day of student learning which is seen from the school education calendar and the place of this study, namely in SMAN 1 Sawan.

\section{Result And Discussion}

\section{Research Results}

In this chapter we will discuss the results of the research which include data descriptions, analysis requirements, and hypothesis testing.

\section{Description of Data}

a. Description of Questionnaire Results

Data From the results of the questionnaire given to all $\mathrm{X}$ Language classes. There were two classes that met the criteria, namely in class X IBB 1 and X IBB2. Obtained data on class X IBB 1 tendency of personality type IBB1 class X students, namely students with Extroverted personality numbered 24 students and Introverted students numbered 12 students. Whereas in class X IBB 2 the tendency of students who have Extrovert personality is 16 students and students who have Introverted personalities amount to 18 students. So the total number of students who have an Extrovert personality is 40 people and students who have an Introverted personality are 30 people.

\section{b. Description of Learning Outcomes Data \\ Student Speaking Skills \\ Extroverted Personality}

The learning outcomes of extroverted students are taken from the material taught at that time by Indonesian teachers in the even semester of the 2018/2019 academic year. The material taught at that time was debate. At the time of the debate material researchers took scores on speaking skills. The minimum completeness criteria (KKM) for Indonesian language lessons in class X Language at that time was 70 and using the 2013 curriculum. All students fulfilled the minimum completeness criteria determined by the school.

40 extroverted students. From the data obtained the speaking skill score is different. There are students who score their speaking skills above kkm and there are also students who score speaking skills according to $\mathrm{kkm}$ and there are even students whose high extrovert personality scores have perfect scores.

\section{c. Description of Learning Outcomes Data \\ Student Speaking Skills \\ Introverted Personality}

The learning outcomes of these introverted students are taken from the material taught at that time by Indonesian language teachers in the even semester of the 2018/2019 academic year. The material 
taught at that time was about debate. At the time of the debate material researchers took scores on speaking skills. when the debate material the researcher took the score of speaking skills. The minimum completeness criteria (KKM) for Indonesian language lessons in class X Language at that time was 70 and using the 2013 curriculum. All students fulfilled the minimum completeness criteria determined by the school.

From the results of the score obtained 30 students with introverted personality, have different speaking scores. There are students whose speaking skills score is higher than kkm, there are students who score their speaking skills are lower than other friends and some are KKM standards.

\section{d. Description of Data Analysis Results}

The data analysis used in this study is using the t-test and manova test. Before carrying out the test the following is the result of a summary of the results of the Post-Test data analysis presented in the following table:

Table 1. Summary of Post-Test Data Analysis Results

\begin{tabular}{llllr}
\hline & & Descriptive Statistics & & \\
& Kelompok & Mean & Std. Deviation & N \\
\hline Keterampilan Berbicara & Ekstrovert & 83.4750 & 1.81147 & 40 \\
& Introvert & 79.6000 & 1.61031 & 30 \\
& Total & 81.8143 & 2.58363 & 70 \\
\hline
\end{tabular}

Based on Table 1, it can be seen that the average value of speaking skills in extroverted students is higher than introverted students, ie extroverted students have an average score of 83.47 and students with introverted personality are 79.6 with a total average of 81.8 .

\section{Requirements for Analysis}

The analysis prerequisite test is carried out before conducting a hypothesis test (t-test), there are several analytical prerequisites that must be met, including univariate normality test and variance homogeneity test from the data obtained (Candiasa, 2010a).

a. Univariate Normality Test Results

To test univariate normality the distribution of data in this study used the Kolmogorov Smirnov Test. The research hypothesis in Uji Kolmogorov Smirnov is as follows.

$H_{0}=$ data comes from the population

normal distribution

$H_{a}=$ data does not come from the

Population normal distribution

Table 2. Test Result Summary Univariate Normality

\begin{tabular}{|c|c|c|c|c|c|c|c|}
\hline & \multirow{2}{*}{ kepribadian } & \multicolumn{3}{|c|}{ Kolmogorov-Smirnova } & \multicolumn{3}{|c|}{ Shapiro-Wilk } \\
\hline \multirow{3}{*}{ Bicara } & & Statistic & Df & Sig. & Statistic & $\mathrm{df}$ & Sig. \\
\hline & Ekstrovert & .114 & 40 & $.200^{*}$ & .965 & 40 & .243 \\
\hline & Introvert & .131 & 30 & .197 & .969 & 30 & .509 \\
\hline
\end{tabular}

a. Lilliefors Significance Correction

*. This is a lower bound of the true significance.

The results of the calculation of the normality of students' speaking skills data in table 02 above show that the significance values obtained are greater than the specified level of significance (5\%). the data is normally distributed.

b. Variant Homogeneity Test Results

The homogeneity of the variance data of students' speaking skills were analyzed by the Levene test with the criteria that the two groups had homogeneous variance if the significance values obtained were greater than the predetermined significance values (5\%). The results of the variance homogeneity test can be seen in Table 01 below in the Levene's Test for Equality of Variances column. Because the 
significance value obtained by speaking skills is 0.448 , the two values are greater than 0.05 or $5 \%$. So that it can be concluded that the data has a homogeneous variance.

c. T-test results

Based on the results of the normality and homogeneity tests of variance, it was found that the distribution of data on speaking skills was normally distributed and had homogeneous variances. Therefore, hypothesis testing can be continued with the t-test.

Table 3. T-Test Result Summary

\section{Independent Samples Test}

\begin{tabular}{|c|c|c|c|c|c|c|c|c|c|c|}
\hline \multicolumn{11}{|c|}{ Independent Samples Test } \\
\hline & & \multicolumn{2}{|c|}{$\begin{array}{l}\text { Levene's } \\
\text { Test for } \\
\text { Equality of } \\
\text { Variances }\end{array}$} & \multicolumn{7}{|c|}{ t-test for Equality of Means } \\
\hline \multirow{4}{*}{ bicara } & \multirow[b]{3}{*}{$\begin{array}{l}\text { Equal } \\
\text { variances } \\
\text { assumed }\end{array}$} & & & & & Sig. (2- & Mean & Std. Error & $\begin{array}{r}95 \% \mathrm{Co} \\
\text { Interva } \\
\text { Diffe }\end{array}$ & $\begin{array}{l}\text { fidence } \\
\text { of the } \\
\text { ence }\end{array}$ \\
\hline & & $\mathrm{F}$ & Sig. & $\mathrm{T}$ & Df & tailed) & Difference & Difference & Lower & Upper \\
\hline & & .583 & .448 & 9.282 & 68 & .000 & 3.87500 & .41748 & 3.04193 & 4.70807 \\
\hline & $\begin{array}{l}\text { Equal } \\
\text { variances not } \\
\text { assumed }\end{array}$ & & & 9.441 & 65.977 & .000 & 3.87500 & .41045 & 3.05550 & 4.69450 \\
\hline
\end{tabular}

From Table 3 above, a significance value for speaking skills is obtained is 0,000 and this value is much smaller than the significance value of $5 \%$. This means that there is an influence between the personality of students and their speaking skills. To see how much influence personality has on speaking skills and see which is better, it can be done by looking at the average value in each group. In this study the average for students who have extroverted personality is higher than the group of students who have introverted personality (can be seen in table 02). So that from the results of the analysis it can be concluded that students who have extroverted personality speaking skills are better than students who have introverted personality.

\section{Test the Research Hypothesis}

The Hypothesis test states that there is an influence of student personality on the speaking skills of class X students of Sawan 1 Public High School. Hypothesis testing is done by t-test. It can be seen in Table 03 there is a summary of the t-test results.

From table 03 above, obtained a significance value for speaking skills is 0,000 and this value is much smaller than the significance value of $5 \%$. This means that there is an influence between the personality of students and speaking skills. seen from the average or mean. Students with extroverted personalities have an average of 83.4. While students with introverted personality have an average or mean of 79.6. When viewed from this average, it means that students with extroverted personality speaking skills tend to be superior to students who have Introverted personality.

So, based on the results of hypothesis testing it can be concluded that simultaneously there is an influence of personality on speaking skills of class X SMA N 1 Sawan students and the average student who has an Extrovert personality tends to have higher speaking value than Introverted students.

\section{Discussion}

The Influence of Personality on Speaking Skills of Class X Students of SMA The purpose of this study is to analyze the influence of personality on speaking skills. The results showed that there were influences of personality which in this case were the personality of extroverted students with introverts with speaking skills. This is based on the results of the analysis using a t-test that obtained a significance value of 0,000 less than 0,005 and seen from the average acquisition value of speaking skills of extroverted students, that is equal to 83.47 compared to introverted students of 79.60 . So that HO is rejected and $\mathrm{H} 1$ is accepted. This means that there is a significant influence between personality especially students who have Extrovert and Introvert personality with speaking skills. 
Extroverted and introverted personality types are two personality types, each of which has its own characteristics. Because both of these personality types have their own characteristics, this greatly influences the learning outcomes of students speaking X language in SMA 1 Sawan. According to Eysenck (1965) saying that Extroverted personalities are generally friendly, sociable, like to party, have lots of friends, need other people to talk and do not like to read or study alone. Because it is easy to get along, it requires other people to converse and in line with what Luthans (2011:132) says that students who have extraversion are sociable, friendly, talkative and confident. Agreeableness has the characteristics of being able to work same (cooperative), warm, caring, polite, trustworthy. Seriousness (conscientiousnes) has characteristics that are trustworthy, hard working, organized, disciplined, diligent and responsible, a personality that has a stable emotion will be characterized by calm, feeling safe, happy and not worried which makes students with extroverted personality succeed in speaking skills.

Compared with students who have introverted personalities in the X Language class. The students tend to be quiet, passive and timid. In the communication situation in this case speaking tends to be more silent in line with what was said by Supriadi (2012: 180) who said students with introverted personality tended to be asocial, quiet, passive, doubtful, thoughtful, sad, obedient, pessimistic, timid. People tend to have a negative self-concept because they lack confidence and avoid communication with others. He was afraid that other people would ridicule him. In a communication situation, he will be more silent (Supriadi, 2012: 180). In addition, students with introverted personality will experience interference or obstacles in interpersonal communication.

Extroverted and introverted personality types are two different groups of attitudes, which students possess so that they are characteristic of the students in adapting to the environment that appears in activities, fun, courage to take risks, obedience to encouragement, statement of feelings, depth of thinking, and responsibility . The difference between extrovert and introverted personality is only to emphasize the orientation of his attitude towards his environment not on differences in his cognitive abilities. Extroverted students do not mean smarter than introverted students in accepting, thinking about, and solving problems in building their knowledge of all the information / stimuli they face. It is possible that extroverted students differ in their learning outcomes with a group of introverted students, but that difference occurs because of their tendency to focus attention in learning and processing teaching materials by utilizing stimulation that is in accordance with their characteristics (Larsen in Indrawati, 2019).

In addition, according to Iwi Afifah (2016) communication skills are one way for teens to express something that is on their mind. There is a tendency that adolescents who have low communication skills can be said to be someone with an introvert personality. Such personalities tend to close themselves with others and prefer to harbor what is felt. With the communication skills in adolescents, teenagers will really be able to express what is desired and other people will also know what the teenager really wants. When that happens, he can also evaluate the good or bad of what has been revealed, so that he will be able to improve the attitude or behavior that is not good and in the end the teenager will be able to develop optimally.

In addition, according to research by Dian Rusdiana Triastusi (2016) entitled "Collaboration of Types of Personality with Ability to Communicate Students of MI Ma'arif Al-Ishlah Kalisat Bungkal Ponorogo Academic Year 2015-2016" states personality types can affect students' communication skills. From the results of research conducted in class IV and V of Ma'arif Al-Ishlah Kalisat Bungkal Ponorogo 2015-2016 Academic Year using the formula of the contingency coefficient correlation statistics the results stated there was a positive correlation between personality types with communication skills of class IV and V MI Ma 'arif Al-Ishlah Kalisat Bungkal Ponorogo for 2015-2016 Academic Year with a correlation of 0.610 classified as a strong correlation.

Based on the differences in characteristics found in students with extroverted and introverted personality types above, actually this is what causes a very large influence on speaking skills. In addition, the existence of relevant research results that further strengthen this research, which states the existence of the influence of personality on student communication skills. However, in this study, the speaking skills of students with extroverted personality were of higher speaking intensity than students with introverted personalities

\section{Conclussion}

Based on theoretical studies and research that has been carried out to discuss the influence of personality on speaking skills and students of class X Language Sawan 1 Public High School, it can be concluded that Based on the results of the analysis using the $t$-test obtained a significance value of 0,000 less than 0.005 and seen from the average acquisition value the speaking skills of extroverted students are 
83.47 greater than introverted students, which is 79.60 . So that $\mathrm{H} 0$ is rejected and $\mathrm{H} 1$ is accepted. This means that there is a significant influence between personality and speaking skills at SMA 1 Sawan.

\section{Reference}

Aisyah,Siti dkk. 2007. Perkembangan dan Konsep Dasar Pengembangan Anak Usia Dini. Jakarta: Universitas Terbuka.

Boeree, George. 2016. Melacak Kepribadian Anda Bersama Psikologi Dunia. Jogjakarta : Ar Ruzz Media

Boeree, George. 2016. General Psychology Psikologi Kepribadian, Persepsi, Kognisi, Emosi, \& Prilaku. Jogjakarta : Ar Ruzz Media

Brown, Douglas H. 2008. Prinsip pembelajaran dan Pengajaran Bahasa. Jakarta : Pearson Education

Bungin, Burhan, 2009. Metodologi Penelitian Kuantitatif. Jakarta:Kencana Prenada Media Group

Burdenski Jr, T. K. (2000). Evaluating Univariate, Bivariate, and Multivariate Normality Using Graphical Procedures.

Candiasa, I. M. (2010a). Statistik Multivariat Disertai Aplikasi SPSS. Singaraja: Universitas Pendidikan Ganesha.

Dalman.(2015). Menulis karya ilmiah.Depok: Rajagrafindo Persada.

Dantes. 2012. Metode Penelitian. Yogyakarta : CV Andi Offset

Darmawan, D. (2014). Metode penelitian kuantitatif. Bandung: remaja rosdakarya.

Dwipayana, I Gede Fajar Krisna. 2016. Pengaruh Konseling Behavioral Dengan Teknik Modeling dan Teknik Role Playing Terhadap Self Confidence ditinjau dari kecenderungan kepribadian Ekstrovert dan Introvert Siswa Kelas X Mipa SMA Negeri 4 Singaraja. Skripsi Pendidikan Bimbingan Konseling. Singaraja: Universitas Pendidikan Ganesha

Hamdani. 2015. Hubungan Kepribadian Siswa Dengan Prestasi Belajar Siswa Kelas XI Pada Mata Pelajaran IPS Terpadu”Jurnal Program Studi Pendidikan Ekonomi FKIP Untan Pontianak Vol 4 no 11.

Iwi Afifah, Elian dkk. 2016. Pengembangan Media Letter Sharinguntuk Meningkatkan Keterampilan Komunikasi Siswa introvert. Universitas Negeri Malang.Jurnal Kajian Bimbingan dan Konseling.Vol. 1, No. 1, 2016, hlm. 27-32.

Jani, Natasari Sinulingga. 2016. Kepribadian dan Efikasi Diri Dengan Motivasi Belajar Siswa Kelas V Sekolah Dasar. Universitas Mutiara Nusantara Medan. Jurnal Pendidikan Dasar Vol 7 Edisi I

Mita, Yuliana Kristiyani. 2009. Hubungan Anatra Tipe Kepribadian Ekstrovert-Introvert Dengan Orientasi Keterampilan Komunikasi Interpersonal Pada Distributor Multi Level Marketing Tianshi. Yogjakarta: Universitas Sanata Darama Yogyakarta.

Nana Syaodih Sukmadinata. (2004). Landasan Psikologi Proses Pendidikan. Bandung: Remaja

Sugiyono.(2008). Metode Penelitian Pendidikan. : Bandung: Alfabeta.

Sugiyono. 2016. Metode Penelitian Kuantitatif, Kualitatif dan R \& D. Bandung: Alfabeta

Syafi'ie, I. 1988. Retorika dalam Menulis. Jakarta: Depdikbud.

Yusuf, Syamsu. 2004. Psikologi Perkembangan Anak dan Remaja. Bandung: Rosda Karya

Yusuf, Syamsu dan Nurihsan, A.J. 2005. Landasan Bimbingan dan Konseling. Bandung: Rosda Karya 